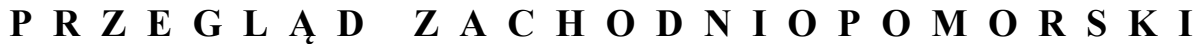 ROCZNIK XXXIII (LXII) ROK 2018 ZESZYT 3
}

\author{
URSZULA KoZlOWSKA \\ Wydział Humanistyczny, Uniwersytet Szczeciński \\ e-mail: urszula.kozlowska@usz.edu.pl
}

\section{W POSZUKIWANIU MODELU OCHRONY ZDROWIA W POWOJENneJ Polsce - OD PAŃSTwOWEJ SŁUŻBy ZDRowia DO PUBLICZNEJ OPIEKI ZDROWOTNEJ (1945-2009)}

Słowa kluczowe: ochrona zdrowia, Polska Ludowa, III Rzeczpospolita Polska Keywords: health care, People's Poland, III Republic of Poland

Wprowadzanie reform w różnych dziedzinach życia społecznego jest działaniem zrozumiałym i koniecznym. Z założenia mają one wpłynąć na poprawę danego sektora, jego usprawnienie. System ochrony zdrowia i jego odpowiednie funkcjonowanie jest uwarunkowane różnorodnymi czynnikami, wśród których mądrość podejmowanych rozwiązań na rzecz jego sprawnego działania wydaje się być jednym z ważniejszych.

Celem pracy jest ukazanie modelu ochrony zdrowia, sposobu jego kształtowania w okresie Polski Ludowej oraz w III Rzeczypospolitej. Artykuł stanowi szersze tło do dalszych rozważań na temat ochrony zdrowia na Pomorzu Zachodnim. Należy nadmienić, że zwłaszcza pierwszy etap, tj. tworzenie struktur państwowej służby zdrowia, przebiegał w bardzo trudnych warunkach na analizowanym terenie, gdyż należało zbudować ją od podstaw, przygotować pod względem organizacyjnym i merytorycznym, a przede wszystkim zaspokoić potrzeby zdrowotne ludności. W zupełnie innych warunkach przebiegał natomiast drugi etap organizacji ochrony zdrowia na Pomorzu Zachodnim, który przypadł na lata 90. $\mathrm{XX}$ wieku, kiedy to opieka zdrowotna przechodziła transformację z państwowej 
na publiczną. Nie trzeba było wówczas „od początku” budować polskiej służby zdrowia, należało jedynie wprowadzić zmiany wynikające z obowiązującego ustawodawstwa.

W latach 1945-2009 system ochrony zdrowia w Polsce ulegał różnorodnym przeobrażeniom. Ich charakter był uzależniony od aktualnie panujących warunków społecznych, gospodarczych, politycznych. Przebiegały one od systemu centralnie sterowanego do systemu opartego na zasadach wolnego rynku. Okres ten można podzielić na dwa istotne etapy: pierwszy, obejmujący lata 1948-1991, kiedy to w wymiarze ochrony zdrowia obowiązywał wyłączny monopol państwa na prowadzenie zakładów opieki zdrowotnej, oraz po 1991 roku, kiedy to faktycznie rozpoczęła się reforma systemu ochrony zdrowia, której efektem było przyjęcie Ustawy o zakładach opieki zdrowotnej. Wspomniany dokument ograniczał wyłączność państwa w wymiarze nadzoru i prowadzenia zakładów opieki zdrowotnej. Ponadto ustawa zrywała z pojęciem ,państwowej i społecznej służby zdrowia", wprowadzając w to miejsce publiczne zakłady opieki zdrowotnej. Pozwoliła również na budowanie rynku usług medycznych oraz tworzenie i rozwijanie sektora prywatnego w opiece zdrowotnej ${ }^{1}$.

\section{Specyfika państwowej służby zdrowia}

W Polsce po zakończeniu działań wojennych podjęto kroki w kierunku ukształtowania odpowiedniej polityki zdrowotnej służącej ogółowi społeczeństwa. Uznano, że upowszechnienie i udostępnienie pomocy lekarskiej, zakładowej, ambulatoryjnej i uzdrowiskowej wszystkim cierpiącym, a więc szeroka „demokratyzacja lecznictwa”, to istotny cel w organizacji powojennej służby zdrowia. Aby mógł on zostać zrealizowany, należało wszelkie sprawy związane z organizacją ochrony zdrowia scalić w Ministerstwie Zdrowia, będącym jedynym ośrodkiem decyzyjnym ${ }^{2}$. Wyraz ujednoliconego modelu ochrony zdrowia, do którego należało dążyć, najtrafniej oddają słowa ówczesnego ministra zdrowia: „[należy] stworzyć jednolitą służbę zdrowia i postawić [ją] na takim poziomie, aby dawała możliwie najdoskonalszą opiekę lekarską wszystkim obywatelom

1 M. Dobska, K. Rogoziński, Podstawy zarzadzania zakładem opieki zdrowotnej, Warszawa 2008, s. 13; S. Poździoch, Regulacje prawne w dziedzinie zdrowia publicznego w Polsce, w: Zdrowie publiczne, red. A. Czupryna, S. Poździoch, A. Ryś, W.C. Włodarczyk, Kraków 2001, s. 217; Ustawa z dnia 30 sierpnia 1991 r. o zakładach opieki zdrowotnej, Dz.U. 1991 nr 91, poz. 408.

2 Zjazd Naczelników Wojewódzkich Wydziałów Zdrowia, Archiwum Akt Nowych (dalej: AAN), Ministerstwo Zdrowia (dalej: MZ), sygn. 14, k. 85-87. 
Państwa. Reforma lecznicza musi pójść w tym kierunku, aby [...] wszyscy w jednakowej mierze [...] [mieli] możność korzystania z pomocy lekarskiej”3. Jednak powojenna rzeczywistość odbiegała od przyjętych formalnych założeń. Spuścizna odziedziczona po dwudziestoleciu międzywojennym w postaci wielosektorowości zdrowia publicznego w znaczący sposób wpływała na politykę zdrowotną realizowaną po drugiej wojnie światowej.

Utworzenie 11 kwietnia 1945 roku Ministerstwa Zdrowia, jako specjalnego działu administracji państwowej, było ważnym działaniem podkreślającym wagę i znaczenie zagadnień zdrowotnych. Należy jednak zaznaczyć, że problemy zdrowia znajdowały się w gestii nie tylko tego resortu, ale i różnych innych ministerstw oraz instytucji, które musiały uwzględniać zasady polityki zdrowotnej opracowane przez Ministerstwo Zdrowia. Ówczesny minister zdrowia, dr Franciszek Litwin, w przemówieniu na posiedzeniu Krajowej Rady Narodowej wskazywał, że właściwe ministerstwo skupia jedynie $20 \%$ zagadnień leczniczych, istnieje zaś blisko 30 różnych instytucji, którym ta problematyka nie jest $\mathrm{obca}^{4}$. Prócz Ministerstwa Zdrowia, zajmującego się państwową służbą zdrowia, sprawy zdrowia społeczeństwa należały również do kompetencji Ministerstwa Administracji Publicznej, któremu podlegało lecznictwo samorządowe, Ministerstwa Odbudowy, zajmującego się inwestycjami związanymi ze służbą zdrowia, Ministerstwa Oświaty, w gestii którego znajdowały się uniwersyteckie wydziały medyczne, opieka nad dzieckiem itd., Ministerstwa Aprowizacji i Handlu, zajmującego się pomocą dzieciom w zakresie wyżywienia i ochrony zdrowia, Ministerstwa Przemysłu, odpowiedzialnego za przemysłową służbę zdrowia i produkcję leków, Ministerstwa Rolnictwa i Reform Rolnych, Ministerstwa Ziem Odzyskanych (od 13 listopada 1945 r.). Oddzielną służbę zdrowia miały także resorty komunikacji, obrony narodowej, bezpieczeństwa publicznego. Sprawami zdrowia zajmowały się również Państwowy Urząd Repatriacyjny, Polski Czerwony Krzyż oraz Ubezpieczalnia Społeczna, świadcząca usługi w zakresie lecznictwa pracowniczego, a podlegająca Ministerstwu Pracy i Opieki Społecznej. Wielo-

\footnotetext{
3 Aktualne zagadnienia stużby zdrowia [artykuł redakcyjny], „Dziennik Zdrowia” 1945, nr 1, s. 48 .

4 Posiedzenie Komisji Zdrowia z 10 sierpnia 1945 r., Referat Ministra Zdrowia, AAN, Biuro Prezydialne Krajowej Rady Narodowej Komitet Centralny, sygn. 76, k. 6; Posiedzenie Komisji Zdrowia z 10 sierpnia 1945 r. Referat Ministra Zdrowia.

5 Z. Jastrzębowski, Spory o model lecznictwa. Opieka zdrowotna w koncepcjach polskiej polityki społecznej w XIX i XX wieku (do 1948 r.), Łódź 1994, s. 206; E. Więckowska, Zwalczanie ostrych chorób zakaźnych w Polsce w latach 1944-1950, Wrocław 2001, s. 36.
} 
sektorowy model służby zdrowia obowiązujący w pierwszych latach po wyzwoleniu był realizowany przez różne instytucje i segmenty administracji. Opiekę nad zdrowiem ludności sprawowały zarówno instytucje państwowe, samorządowe, ubezpieczeń społecznych, jak i inne organizacje publiczne oraz społeczne. W funkcjonowaniu tego modelu pomocne okazały się przedwojenne przepisy prawne ${ }^{6}$. Należy jednak zaznaczyć, że opierając się na przedwojennym ustawodawstwie, realizowano nowe cele. Jednym z nich było rozszerzenie zadań leczniczych na rzecz całej ludności.

Jak zaznacza Zbigniew Jastrzębowski, po zakończeniu działań wojennych poszukiwano właściwej drogi organizowania systemu ochrony zdrowia. Można wskazać dwa etapy kształtowania się „koncepcji opieki zdrowotnej”. Pierwszy z nich obejmował lata 1944-1947, kiedy to poszukiwano modelu powszechnej służby zdrowia. Środowisko lekarskie i działacze społeczni byli zdania, że należy go wprowadzać stopniowo, mając na uwadze sytuację społeczno-gospodarczą kraju. Społeczna opieka zdrowotna miała być oparta na dwóch istotnych kwestiach: ubezpieczeniach społecznych, stopniowo rozszerzanych na różne kategorie społeczne, oraz na scaleniu, skoordynowaniu placówek leczniczych i stopniowym ich przejmowaniu przez samorządy. Jednak opieszałość Ministerstwa Zdrowia hamowała wprowadzenie nowych rozwiązań w zakresie opieki zdrowotnej, stąd przygotowywana od dłuższego czasu ustawa dotycząca publicznej służby zdrowia nie została wprowadzona w życie.

Drugi etap w rozwoju powojennej służby zdrowia rozpoczął się w połowie 1947 roku. Wtedy to pod kierownictwem ówczesnego wiceministra zdrowia, dr. Jerzego Sztachelskiego, opracowano projekt ustawy o strukturze organizacyjnej społecznej służby zdrowia7. Projekt ten był podstawą do wprowadzenia w życie ustawy z dnia 28 października 1948 roku o zakładach społecznych służby zdrowia i planowej gospodarce w służbie zdrowia ${ }^{8}$. Ustawa zapoczątkowała nowy etap $\mathrm{w}$ organizacji powojennej ochrony zdrowia, związany z przebudową systemu ochrony zdrowia w kierunku ujednolicenia, oraz umożliwiała jego

${ }^{6}$ Ustawa o obowiązkowym ubezpieczeniu społecznym, Dz.U. $1933 \mathrm{nr}$ 51, poz. 395.

7 Rozporządzenie (projekt) Ministra Zdrowia w porozumieniu z Ministrami: Pracy i Opieki Społecznej, Oświaty, Administracji Publicznej i Ziem Odzyskanych O strukturze organizacyjnej społecznej slużby zdrowia, AAN, MZ, sygn. 22, k. 146.

8 Z. Jastrzębowski, Spory o model lecznictwa..., s. 267-268; Ustawa z dnia 28 października 1948 r. o zakładach społecznych służby zdrowia i planowej gospodarce w służbie zdrowia, Dz.U. 1948 nr 55, poz. 434. 
organizację na podstawie rozwiązań radzieckich. Według niektórych badaczy dokument ten był przełomowy - jego rewolucyjność wiązała się z wyznaczeniem „kierunku rozwoju socjalistycznego systemu ochrony zdrowia”, zaś o randze świadczyły m.in. następujące rozwiązania: zasady planowej gospodarki, określenie jednego ośrodka kierującego sprawami zdrowotności społeczeństwa, podkreślenie regulacyjnej i organizatorskiej roli państwa w tym wymiarze, określenie zasad prawnych regulujących system opieki zdrowotnej w PRL, dzięki czemu stworzono podstawy do „budowy socjalistycznej bazy materialno-organizacyjnej służby zdrowia"10. Należy jednak zaznaczyć, że ustawa nie likwidowała wielosektorowości w służbie zdrowia. Nadal poza resortem zdrowia pozostawało lecznictwo pracownicze, podlegające Ministerstwu Pracy i Opieki Społecznej. Państwo przejęło inne sektory lecznictwa, tj. organizacji społecznych, charytatywnych, kongregacyjnych, placówki lecznictwa prywatnego oraz samorządowego. W taki sam sposób postąpiono z jednostkami Ubezpieczalni Społecznej ${ }^{11}$. Wprowadzenie ustawy umożliwiało budowanie systemu ochrony zdrowia opartego na rozwiązaniach radzieckich, gdzie państwo było odpowiedzialne za całość polityki zdrowotnej. Rozwijany wówczas system opierał się na „modelu Siemaszki” (model centralnie planowany). Do jego podstawowych zasad zaliczono: centralne sterowanie, zatrudnianie personelu medycznego przez państwo, finansowanie z budżetu państwa, uniwersalny dostęp do służby zdrowia dla całej populacji, pełen zakres bezpłatnych świadczeń zdrowotnych dla ludności z wyjątkiem niektórych leków pozostających w dyspozycji otwartej opieki zdrowotnej ${ }^{12}$. W Polsce model Siemaszki nigdy w całości nie został wprowadzony w życie, co można powiązać z polską specyfiką kulturowo-gospodarczą (m.in. indywidualne rolnictwo), a także zmianami politycznymi po 1956 roku. Można powiedzieć, że była to „polska odmiana modelu Siemaszki”. Przez cały okres Polski Ludowej obok placówek społecznej służby zdrowia funkcjonowały także prywatne gabinety lekarskie

${ }^{9}$ L. Krotkiewska, Rozwój administracji stużby zdrowia w PRL, Warszawa 1968, s. 71.

10 Tamże, s. 69.

11 Z. Jastrzębowski, Spory o model lecznictwa..., s. 250-252, 268.

12 J. Leowski, Polityka zdrowotna a zdrowie publiczne, Warszawa 2009, s. 22-23; W.C. Włodarczyk, Polityka zdrowotna $w$ społeczeństwie demokratycznym, Łódź-Kraków 1996, s. 322; L. Waszkiewicz, Zagadnienia polityki zdrowotnej, w: Zdrowie w medycynie i naukach społecznych, red. T.B. Kulik, I. Wrońska, Stalowa Wola 2000, s. 86-87. 
i spółdzielnie lekarskie. Założenia tego modelu obowiązywały w Polsce do początku lat 90. XX wieku' ${ }^{13}$.

Przekształcenia zachodzące $\mathrm{w}$ organizacji służby zdrowia, ewolucyjne przejście od systemu wielosektorowego do państwowego przebiegały etapami. Kolejno różnorodne zagadnienia, które znajdowały się w kompetencji wielu resortów, były przejmowane przez Ministerstwo Zdrowia. Scalenie służby zdrowia $\mathrm{w}$ wymiarze prawno-organizacyjnym odpowiadało założeniom związanym z lecznictwem społecznym zarówno w wymiarze strukturalnym, jak i zadaniowym. Było również zgodne z centralnym planowaniem, finansowaniem i zarządzaniem. Uważano, że centralizacja lecznictwa rozwiąże różnorodne problemy związane ze służbą zdrowia, przede wszystkim lokalowe, kadrowe czy budżetowe. Ponadto zasada centralizacji w zarządzaniu służbą zdrowia dawała ministrowi zdrowia możliwość wprowadzania nowych sposobów finansowania, pozwalała na wydawanie rozporządzeń określających działalność zamkniętych i otwartych placówek służby zdrowia. Należy także dodać, że przeobrażenia te pozwoliły wykreować jednolity system społecznej służby zdrowia, którego ważnym zadaniem było zapewnienie szerokim rzeszom ludności opieki zdrowotnej. O ile proces scalania i przejmowania przez Ministerstwo Zdrowia różnych placówek związanych ze zdrowiem zakończył się w 1953 roku, to zapewnienie ludności powszechnego dostępu do ochrony zdrowia zostało zrealizowane dopiero na początku lat 70. XX wieku.

Organizacja ochrony zdrowia w okresie Polski Ludowej była bardzo kosztochłonnym zabiegiem. W latach siedemdziesiątych zakłady służby zdrowia zostały zobowiązane do udzielania bezpłatnych świadczeń zdrowotnych zdecydowanej większości ludności (98-99\%), przy czym nie uwzględniono ich możliwości w zakresie pomocy tak dużej liczbie ubezpieczonych. Powstała sytuacja w znaczący sposób obciążyła budżet systemu ochrony zdrowia. Następnym, równie ważnym elementem powojennej organizacji służby zdrowia była jej ekstensywna rozbudowa (obniżanie kosztu pracy personelu, sztuczne ceny leków, aparatury). Wykreowano wówczas pozór dostępności świadczeń, osiągalnych mimo faktycznych ograniczeń i dolegliwości w korzystaniu. Przedstawione wyżej zaniedbania o strukturalnym i historycznym charakterze doprowadziły do dramatycznej sytuacji systemu ochrony zdrowia w Polsce, która w całości ukazała się w latach

13 J. Leowski, Polityka zdrowotna..., s. 23, 163. 
osiemdziesiątych, stanowiąc podstawę do przeprowadzenia reform tego wymiaru życia społecznego ${ }^{14}$.

System ochrony zdrowia ukształtowany i obowiązujący w Polsce Ludowej, z monopolem państwa, nie był w stanie spełnić podstawowego zadania, jakim było obiektywne i subiektywne bezpieczeństwo obywateli w wymiarze ochrony zdrowia ${ }^{15}$. Niekorzystne zmiany w sytuacji zdrowotnej ludności zaobserwowano już w latach siedemdziesiątych, zaś kolejna dekada przyniosła jeszcze gorsze wskaźniki zdrowotne społeczeństwa. Wzrost występowania tzw. chorób cywilizacyjnych, głównie układu krążenia, chorób nowotworowych, przewlekłych chorób układu oddechowego, wypadków i urazów wynikających głównie ze starzenia się ludności, trudnych warunków życia i pracy, a także degradacji środowiska przyrodniczego, tworzył obraz sytuacji zdrowotnej ludności w latach osiemdziesiątych. Niepokojącym zjawiskiem był także wzrost odsetka ludzi niepełnosprawnych i przewlekle chorych. Ponadto innym niekorzystnym wskaźnikiem była umieralność niemowląt oraz oczekiwana przeciętna długość życia. W tym wymiarze Polska na tle krajów OECD (Organizacja Współpracy Gospodarczej i Rozwoju) prezentowała gorsze wskaźniki. Wydaje się zatem, że główne czynniki związane z krytyką systemu ochrony zdrowia w latach osiemdziesiątych były $\mathrm{w}$ dużej mierze związane $\mathrm{z}$ sytuacją zdrowotną ludności oraz niewydolnością organizacyjno-funkcjonalną systemu. Innym elementem, który leżał u podstaw narastającego niezadowolenia, było ,akcentowanie przez państwo [...] odpowiedzialności za całokształt spraw zdrowia obywateli"'16. Sytuacja ta powodowała, że społeczeństwo czuło się zwolnione z troski o swoje zdrowie - to system miał zaspokoić wszystkie potrzeby zdrowotne. Ingerencja i nadzór państwa w wymiar ochrony zdrowia wykreowały negatywne zjawisko „uzależnienia” obywateli od programów państwowych. Sytuacja taka w zasadniczy sposób wpłynęła na aktywność obywateli w sferze zdrowia, a jej wskaźnikiem było między innymi nikłe zainteresowanie profilaktyką czy promocją zdrowia.

Wśród różnorodnych przyczyn argumentujących potrzebę wprowadzenia reform systemu ochrony zdrowia w latach osiemdziesiątych należy wymienić:

- centralizację decyzji oraz nadmiernie rozbudowaną biurokrację,

14 W.C. Włodarczyk, Reforma opieki zdrowotnej w Polsce. Studium polityki zdrowotnej, Kraków 1998, s. 188.

15 G. Ciura, Ochrona zdrowia, w: Koncepcje polityki społecznej w Polsce 1989-1991, red. J. Hryniewicz, raport BSE nr 12, Warszawa 1992, s. 49.

16 J. Leowski, Polityka zdrowotna..., s. 164; G. Ciura, Ochrona zdrowia..., s. 51. 
- upośledzone finansowanie potrzeb opieki zdrowotnej,

- niską efektywność pracy personelu medycznego,

- niedostatki strukturalne w organizacji systemu ochrony zdrowia na poziomie lokalnym,

- nieprzestrzeganie praw społeczeństwa, pacjentów do współdecydowania w zagadnieniach dotyczących ich zdrowia,

- brak udziału społeczeństwa w procesie kontroli nad działalnością systemu ${ }^{17}$.

Elementy te tworzyły obraz niewydolnego systemu opieki zdrowotnej. Niewydolność ta pociągała za sobą także inne konsekwencje, wśród których jako najistotniejsze należy wymienić utratę poczucia bezpieczeństwa zdrowotnego, pogarszający się stan zdrowia ludności oraz wzrost kosztów leczenia ${ }^{18}$.

\section{Ochrona zdrowia w Polsce po 1989 roku}

Przemiany ustrojowe w Polsce po 1989 roku wyznaczyły następny etap w reformowaniu opieki zdrowotnej. Ważne w tym wymiarze prace przypadły na lata 1989-1992. W okresie posolidarnościowych rządów położono podwaliny pod organizowanie nowego systemu ochrony zdrowia. Jednym z projektów reformujących sektor zdrowia był dokument strony solidarnościowo-opozycyjnej, który powstał w podzespole Okrągłego Stołu do spraw zdrowia. Składał się on z 14 założeń dotyczących reformy służby zdrowia ${ }^{19}$. Nie był to jednak jedyny tego typu dokument. Pojawiły się także inne projekty, inicjatywy proponujące różnorodne rozwiązania, jak choćby autorski projekt (Projekt reformy systemu opieki zdrowotnej) będący koncepcją procesu reformatorskiego, zaproponowany przez grupę ekspercką Centrum Organizacji i Ekonomiki Ochrony Zdrowia. Własną, społeczną koncepcję reformy zaproponowało także Ministerstwo Zdrowia i Opieki Społecznej. Wkład w poszukiwanie odpowiednich rozwiązań reformujących opiekę zdrowotną podjęto również pod koniec 1991 roku w Biurze Studiów i Ekspertyz Kancelarii Sejmu. Projekty reformatorskie systemu ochrony zdrowia były również wysuwane przez ugrupowania partyjne. Udział w reformowaniu

17 J. Leowski, Polityka zdrowotna..., s. 165.

18 K. Prętki, Rola i znaczenie dobrowolnych ubezpieczeń zdrowotnych w koncepcjach reformatorskich systemu ochrony zdrowia w Polsce po 1989 r., w: System ochrony zdrowia. Problemy i możliwości ich rozwiąań, red. E. Nojszewska, Warszawa 2011, s. 126.

19 M. Woch, Instytucje ksztaltujace system opieki zdrowotnej w Polsce (Analiza prawno-porównawcza lat 1918-2004), Warszawa 2012, s. 85-86. 
systemu ochrony zdrowia w Polsce wzięły także instytucje międzynarodowe. Wśród koncepcji, które wówczas opracowywano, na uwagę zasługuje przede wszystkim ta sformułowana przez Bank Światowy.

Wśród różnorodnych postulatów głównie zwracano uwagę na: zmniejszenie zależności od programów rządowych, kontrolę i nadzór ze strony społeczeństwa, podkreślenie praw pacjenta, podmiotowość pracowników ochrony zdrowia, reformę ubezpieczeń zdrowotnych, promocję zdrowia i działalność zapobiegawczą, odpowiednią politykę lekową ${ }^{20}$. Ponadto wszystkie projekty dotyczące reformy ochrony zdrowia wskazywały, że jedynie gruntowna przebudowa tego sektora może przynieść poprawę opieki zdrowotnej.

Analizując działania podejmowane w kierunku reformowania ochrony zdrowia w latach dziewięćdziesiątych, warto także zwrócić uwagę na dwa dokumenty z 1990 roku, określające kierunki zmian. Mowa tu przede wszystkim o programie Kierunki zmian $w$ organizacji i finansowaniu opieki zdrowotnej. Proces reformowania opieki zdrowotnej, w którym dokonano analizy sytuacji zdrowotnej społeczeństwa polskiego oraz wskazano drogi reformowania. Informacje zawarte w tym dokumencie nie zostały wykorzystane, chociaż sam dokument nigdy nie został uchylony ${ }^{21}$. Drugim dokumentem był Narodowy Program Zdrowia (NPZ), który zyskał poparcie Rady Ministrów. Według jego twórców był on ,pierwszą próbą zjednoczenia wysiłków różnych organów administracji rządowej, organizacji pozarządowych oraz społeczności lokalnych w celu ochrony zdrowia, utrzymania i poprawy zdrowia społeczeństwa polskiego"22. Ważnym założeniem programu było przesunięcie punktu ciężkości w kierunku profilaktyki oraz całościowe ujęcie zagadnień zdrowia, w tym jego uwarunkowań. Określone w dokumencie cele strategiczne i operacyjne wskazywały kierunki zmian oraz problemy zdrowotne, na których powinna skupić się reforma tego sektora. Aktualnie obowiązujący NPZ obejmuje lata 2016-2020.

Wielość stanowisk i koncepcji dotyczących reformy ochrony zdrowia w latach dziewięćdziesiątych wiązała się być może z brakiem określonej wizji oraz kształtu analizowanego wymiaru życia społecznego ${ }^{23}$.

\footnotetext{
20 W.C. Włodarczyk, Reforma opieki zdrowotnej w Polsce..., s. 196-208.

21 Woch M., Instytucje ksztattujace system opieki zdrowotnej w Polsce..., s. 97.

22 Ministerstwo Zdrowia, NPZ 2016-2020, https://www.gov.pl/web/zdrowie/npz-2016-2020.

23 J. Leowski, Polityka zdrowotna..., s. 167.
} 
Przyjęta w 1991 roku ustawa o zakładach opieki zdrowotnej24 (ustawa została znowelizowana 14 lipca 2006 r.) przyniosła rzeczywistą reformę opieki zdrowotnej. Była pierwszym aktem prawnym określającym kształt oraz kierunki reformowania ochrony zdrowia. Wprowadzała istotne rozwiązania, ważne z punktu widzenia prowadzonych reform. Spośród najważniejszych godna uwagi jest koncepcja praw pacjenta, która pozwalała na określenie relacji w układzie pacjent - ochrona zdrowia, dzięki czemu stworzyła bardziej symetryczny układ. Ustawa umożliwiła również budowanie rynku usług medycznych, wprowadzała rozróżnienie publicznych i niepublicznych zakładów opieki zdrowotnej oraz „przekreślała istniejący w latach 1948-1991 wyłączny monopol państwa na prowadzenie zakładów opieki zdrowotnej”25.

Warto dodać, że dla systemu opieki zdrowotnej nie były również obojętne reformy o charakterze administracyjnym. W 1990 roku została przyjęta ustawa o samorządzie terytorialnym ${ }^{26}$, reformująca administrację publiczną, lecz dla opieki zdrowotnej znacznie ważniejsza była ustawa o zakładach opieki zdrowotnej ${ }^{27}$.

W połowie lat 90. podjęto działania, których wynikiem było opracowanie w 1997 roku ustawy o powszechnym ubezpieczeniu zdrowotnym. Generalnie zagadnienie ubezpieczeń zdrowotnych było „fundamentalną kwestią”, podejmowaną już od 1989 roku. Wielomiesięczne prace i dyskusje prowadzone nad dokumentem przyniosły jej nowelizację w 1998 roku, zaś 1 stycznia 1999 roku dokument wszedł w życie. Zaproponowane rozwiązania w wymiarze ubezpieczeń zdrowotnych nawiązywały do doświadczeń z lat 1919-1939 i z okresu po drugiej wojnie światowej (do 1949 r.). Zaproponowane w ustawie rozwiązania (obecne także w innych krajach europejskich i pozaeuropejskich) dotyczyły następujących zagadnień: solidarności społecznej, samorządności, samofinansowania, prawa do wolnego wyboru lekarza i kas chorych, równego dostępu do świadczeń, działalności kas chorych nie dla zysku, gospodarności i celowości działania, gwarancji

${ }^{24}$ Ustawa z dnia 30 sierpnia 1991 r. o zakładach opieki zdrowotnej, Dz.U. 1991 nr 91, poz. 408.

25 S. Poździoch, Regulacje prawne..., s. 317.

26 Ustawa z dnia 8 marca 1990 r. o samorządzie terytorialnym, Dz.U. 1990 nr 16, poz. 95; Ustawa o z dnia 17 maja 1990 r. o podziale zadań i kompetencji określonych w ustawach szczególnych pomiędzy organy gminy a organy administracji rządowej oraz o zmianie niektórych ustaw, Dz.U. 1990 nr 34, poz. 198; Ustawa z dnia 24 listopada 1995 r. o zmianie zakresu działania niektórych miast oraz o miejskich strefach usług publicznych, Dz.U. $1995 \mathrm{nr}$ 141, poz. 692; S. Poździoch, Regulacje prawne..., s. 316-317.

27 W.C. Włodarczyk, Reforma opieki zdrowotnej w Polsce..., s. 210. 
państwa dla ubezpieczonych. W artykule 1 ustawy mowa jest o „powszechnym obowiązkowym ubezpieczeniu zdrowotnym"28. Ważność tej ustawy dla reformy systemu ochrony zdrowia wynikała również z całkowitego odejścia od modelu obowiązującego w Polsce Ludowej. Ponadto dokument ten, określający „ubezpieczeniową ochronę zdrowia", stwarzał możliwość konkurencji między podmiotami świadczącymi usługi zdrowotne. Wprowadzał zasady gospodarki wolnorynkowej. Powodował, że w centrum zainteresowania znalazł się klient, zaś ,jakość usług stała się jedyną właściwą drogą poprawy w zarządzaniu w ochronie zdrowia" ${ }^{29}$. Wprowadzony dokument nie był idealny. Spotkał się z krytyką̨ ${ }^{30}$, jednak zasadniczo wpłynął na usprawnienie systemu ochrony zdrowia oraz w większym stopniu niż dotychczas gwarantował obywatelom prawo do ochrony zdrowia ${ }^{31}$.

Niemalże równolegle do reform przebiegających w sferze zdrowia publicznego zachodziły także zmiany w administracji publicznej. 5 czerwca 1998 roku weszła w życie ustawa o samorządzie województwa. W artykule 14 określono zadania samorządu województwa, do których zaliczono między innymi edukację publiczną oraz promocję i ochronę zdrowia ${ }^{32}$. Wymiar zdrowotny jako ważny element sfery życia publicznego został także podkreślony w ustawie o samorządzie powiatowym. Wśród różnorodnych zadań publicznych o charakterze ponadgminnym do zadań powiatu zaliczono również te składające się na zagadnienia zdrowia publicznego (promocja i ochrona zdrowia, pomoc społeczna, polityka prorodzinna, wspieranie osób niepełnosprawnych i inne ${ }^{33}$. Dokumenty te, podobnie jak i ustawa o samorządzie gminnym, podkreślały wagę i znaczenie ochrony zdrowia. W pewien sposób także korespondowały z tymi, które w sposób bezpośredni dotyczyły systemu zdrowotnego. Dzięki wspomnianym ustawom

28 Ustawa z dnia 6 lutego 1997 roku o powszechnym ubezpieczeniu zdrowotnym, Dz.U. 1997 nr 28, poz. 153; zob. także: S. Poździoch, Regulacje prawne..., s. 320.

29 Konstytucja Rzeczypospolitej Polskiej z dnia 2 kwietnia 1997 roku, Dz.U. 1997 nr 78, poz. 483, art. 61 ust. 1 i 2; zob. także: M. Dobska, K. Rogoziński, Podstawy zarzadzania..., s. 1718; T. Ostrowski, I. Bojar, Systemowy model ochrony zdrowia, w: Zdrowie publiczne, red. T.B. Kulik, M. Latalski, Lublin 2002, s. 115-175.

30 J. Leowski, Polityka zdrowotna..., s. 172.

31 M. Dobska, K. Rogoziński, Podstawy zarządzania..., s. 18.

32 Ustawa z dnia 5 czerwca 1998 roku o samorządzie województwa, Dz.U. 1998 nr 91, poz. 576, art. 14 ust. 1 pkt $1-2$.

33 Ustawa z dnia 5 czerwca 1998 r. o samorządzie powiatowym, Dz.U. 1998 nr 91, poz. 578; J.B. Karski, Polityka zdrowotna samorzadu terytorialnego, Warszawa 2009, s. 39-41; W.C. Włodarczyk, Reformy zdrowotne, Kraków 2003, s. 187-188. 
zagadnienia zdrowia zostały podzielone na realizowane z poziomu rządowego oraz samorządowego.

Zarówno ustawa o zakładach opieki zdrowotnej, jak i obowiązująca od stycznia 1999 roku ustawa o powszechnym ubezpieczeniu zdrowotnym w istotny sposób wpłynęły na reformę ochrony zdrowia w Polsce, stanowiąc podstawową bazę do dalszego jej reformowania. Wspomniane dokumenty określiły nie tylko sposób organizacji ochrony zdrowia w nowej, posttransformacyjnej rzeczywistości, ale i przywróciły podstawowe zasady obowiązujące w tym wymiarze rzeczywistości społecznej, do których można zaliczyć między innymi samorządność, niezależność, autonomię, swobodę działania zakładów opieki zdrowotnej publicznych i niepublicznych czy różnorodność rozwiązań organizacyjnych ${ }^{34}$.

Rok 2003 przyniósł dalsze zmiany w reformowaniu systemu ochrony zdrowia. Likwidacji uległy kasy chorych, do życia powołano natomiast Narodowy Fundusz Zdrowia (NFZ), który miał stać się „lekiem na całe zło”. Prace nad NFZ-em zakończyła ustawa z dnia 23 stycznia 2003 roku o powszechnym ubezpieczeniu zdrowotnym w NFZ ${ }^{35}$. Artykuł 36 dokumentu, ustęp 1 powoływał Narodowy Fundusz Zdrowa, zaś zapis, który znalazł się w artykule 206, ustęp 1 likwidował regionalne kasy chorych, wprowadzając $\mathrm{w}$ ich miejsce wojewódzkie oddziały Funduszu. Ustawa ,podtrzymywała ubezpieczeniowy charakter systemu ochrony zdrowia, który wprowadzała ustawa z 1999 roku o powszechnym

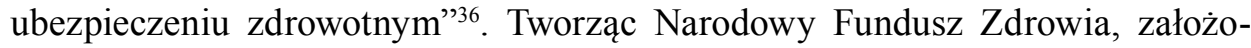
no usprawnienie reform dotyczących systemu ochrony zdrowia. Uregulowania, które on wnosił, miały na celu poprawę sytuacji równego dostępu do świadczeń realizowanych przez zakłady opieki zdrowotnej. Wzmocniono między innymi rolę ministra zdrowia, co wiązało się z przywróceniem konstytucyjnej odpowiedzialności rządu w zakresie ochrony zdrowia. Zmianie uległy także zadania samorządu terytorialnego. Przede wszystkim samorząd wojewódzki zobowiązano do przygotowywania wojewódzkich planów zdrowotnych, zaś organy samorządu powiatowego zyskały uprawnienia opiniodawcze w tym zakresie. W 2004 roku Trybunał Konstytucyjny uznał, że ustawa jest niekonstytucyjna z powodu

34 S. Poździoch, Regulacje prawne..., s. 322

35 Ustawa z dnia 23 stycznia 2003 roku o powszechnym ubezpieczeniu w Narodowym Funduszu Zdrowia, Dz.U. 2003 nr 45, poz. 391.

36 Ustawa z dnia 23 stycznia 2003 roku o powszechnym ubezpieczeniu w Narodowym Funduszu Zdrowia, Dz.U. $2003 \mathrm{nr}$ 45, poz. 391; M. Woch, Instytucje ksztattujące system opieki zdrowotnej w Polsce..., s. 172. 
niejasności i wieloznaczności stosowanych pojęć oraz „z powodu braku ustawowego określenia zakresów świadczeń finansowanych ze środków publicznych, do których każdy obywatel ma prawo" ${ }^{37}$. Stało to w sprzeczności z art. 68 ust. 2 Konstytucji Rzeczypospolitej Polskiej i spowodowało opracowanie nowej ustawy o świadczeniach opieki zdrowotnej finansowanych ze środków publicznych, która została uchwalona w 2004 roku. Wspomniany dokument nie zyskał jednak aprobaty w różnych środowiskach, zgłaszano do niego wiele zastrzeżeń. Kontrowersje budziły liczne niespójności, wśród których istotnym zarzutem był brak odpowiedzialności za realizację zadań wynikających z systemu ubezpieczeniowego ${ }^{38}$.

Warto również wspomnieć, że ważnym krokiem legislacyjnym zmierzającym w kierunku funkcjonowania ochrony zdrowia w warunkach wolnego rynku była także ustawa z dnia 6 listopada 2008 roku o prawach pacjenta i Rzeczniku Praw Pacjenta, obowiązująca od 5 czerwca 2009 roku. Ustawą tą powołano Rzecznika Praw Pacjenta, organ właściwy w sprawach ochrony praw pacjentów: do świadczeń zdrowotnych, do informacji, do żądania nieudzielania przez lekarza informacji $\mathrm{w}$ zakresie wskazanym przez pacjenta, do przedstawienia lekarzowi swojego zdania w zakresie otrzymanych informacji, do dostatecznie wczesnej informacji o zamiarze odstąpienia przez lekarza od leczenia, do tajemnicy informacji związanych z leczeniem, do wyrażania zgody na udzielenie świadczeń zdrowotnych, do poszanowania intymności i godności pacjenta, do umierania w spokoju i godności, do świadczeń zapewniających łagodzenie bólu i innych cierpień w stanie terminalnym, dostępu do dokumentacji medycznej, do zgłaszania sprzeciwu wobec opinii albo orzeczenia lekarza, do poszanowania życia prywatnego i rodzinnego, do opieki duszpasterskiej, do przechowania rzeczy wartościowych w depozycie, do wystąpienia do Rzecznika Praw Pacjen$\mathrm{ta}^{39}$. Zanim wspomniana ustawa została wprowadzona w życie, informacje o prawach przysługujących pacjentowi znajdowały się w różnych dokumentach, więc

\footnotetext{
37 E. Nojszewska, System ochrony zdrowia w Polsce, Warszawa 2011, s. 183.

38 Ustawa z dnia 27 sierpnia 2004 r. o świadczeniach opieki zdrowotnej finansowanych ze środków publicznych, Dz.U. 2004 nr 210, poz. 2135; E. Nojszewska, System ochrony zdrowia...,

39 Ustawa z dnia 6 listopada 2008 r. o prawach pacjenta i Rzeczniku Praw Pacjenta, Dz.U. 2009 nr 52, poz. 417; Ustawa z dnia 24 kwietnia 2009 roku. Przepisy wprowadzające ustawę o prawach pacjenta i Rzeczniku Praw Pacjenta, ustawę o akredytacji w ochronie zdrowia oraz ustawę o konsultantach w ochronie zdrowia, Dz.U. 2009 nr 76, poz. 641; Ustawa z dnia 28 kwietnia 2011 r. o zmianie ustawy o prawach pacjenta i Rzeczniku Praw Pacjenta oraz ustawy o ubezpieczeniach obowiązkowych, Ubezpieczeniowym Funduszu Gwarancyjnym i Polskim Biurze Ubezpieczycieli Komunikacyjnych, Dz.U. 2011 nr 113, poz. 660.
} s. 183. 
uregulowanie praw pacjenta $\mathrm{w}$ jednym miało bardzo duże społeczne znacznie. Dzięki temu podkreślono, że potrzeby pacjentów oraz ich prawa są przestrzegane i chronione przez system ${ }^{40}$. Zmianą na lepsze systemu ochrony zdrowia miała być również tzw. ustawa koszykowa, obowiązująca od 2009 roku ${ }^{41}$. Wspomniany dokument określał zasady kwalifikowania świadczeń zdrowotnych na listę świadczeń gwarantowanych, które częściowo lub całkowicie pokrywane będą ze środków publicznych na podstawie rozporządzeń określających wykaz odrębnych zakresów świadczeń (tzw. koszyków) ${ }^{42}$. Do końca września 2009 roku 13 tego typu dokumentów miało wejść w życie. Ówczesna minister zdrowia, Ewa Kopacz, komentując ustawę uznała, że stanowi ona jeden z etapów naprawy systemu ochrony zdrowia w naszym kraju. Niestety ustawa ta nie spełniła pokładanych w niej nadziei.

Przedstawione rozwiązania prawne regulujące funkcjonowanie sektora ochrony zdrowia stanowią ważny element powstania nowej ochrony zdrowia ${ }^{43}$.

\section{Podsumowanie}

Polska ochrona zdrowia zmaga się z różnymi problemami. Niektóre z nich zostały rozwiązane, inne zaś czekają na swoją kolej. Do tych istotnych należy między innymi wprowadzenie prywatnych ubezpieczeń zdrowotnych, ubezpieczenie zdrowotne rolników, rozwój systemów informatycznych i informacyjnych, a w szczególności rejestru usług medycznych, co pozwoli na wprowadzenie kontroli, nadzoru nad świadczeniodawcami, aptekami oraz ułatwi pracę lekarzom, a także wpłynie na polepszenie bezpieczeństwa zdrowotnego pacjentów. Wypracowany model polityki zdrowotnej funkcjonujący na zasadach wolnego rynku musi także uwzględniać koszty dotyczące ochrony zdrowia. Nie chodzi tu tylko o same koszty związane z leczeniem pacjenta (koszty bezpośrednie), ale i chorowania (koszty pośrednie). Ich znajomość jest bardzo ważna dla gospodarki oraz dla systemu zabezpieczenia socjalnego. Innym zagadnieniem ochrony zdrowia w Polsce, w którym muszą zajść zmiany, jest obszar związany z transgraniczną

40 D. Karkowska, Ustawa o prawach pacjenta i Rzeczniku Praw Pacjenta. Komentarz, Warszawa 2016.

41 Ustawa z dnia 25 czerwca 2009 r. o zmianie ustawy o świadczeniach opieki zdrowotnej finansowanych ze środków publicznych oraz ustawy o cenach, Dz.U. $2009 \mathrm{nr}$ 118, poz. 989.

42 E. Nojszewska, System ochrony zdrowia..., s. 185.

43 Tamże, s. 175. 
opieką zdrowotną. Wprowadzenie tej unijnej dyrektywy ${ }^{44}$ będzie korzystne dla pacjentów, którzy będą mogli dokonać wyboru miejsca leczenia, zwiększy konkurencyjność w ochronie zdrowia oraz przyczyni się do podniesienia jakości świadczeń medycznych. Elementy te w zasadniczy sposób wpłyną na skrócenie czasu oczekiwania na usługę medyczną ${ }^{45}$.

Ochrona zdrowia stanowi specyficzny obszar życia społecznego. Nie ma bowiem kraju, który znalazł złoty środek na jego odpowiednie funkcjonowanie. Być może złożoność tego sektora, wielowymiarowość, różnorodne uwarunkowania i powiązania składają się na trudność jego właściwego działania. Nie bez znaczenia dla sprawnego funkcjonowania systemu ochrony zdrowia pozostaja także różnego rodzaju przemiany polityczne, gospodarcze, społeczne, które tworzą warunki do funkcjonowania określonego modelu ochrony zdrowia i na niego wpływają. Warto również zaznaczyć różnorodność tego sektora w wymiarze historyczno-czasowym. W Polsce poszukiwanie modelu ochrony zdrowia przebiegało od powszechnej służby zdrowia obejmującej lata 1948-1991 do publicznej ochrony zdrowia, której podstawę do funkcjonowania dała ustawa o zakładach opieki zdrowotnej z 1991 roku. Nie można jednak powiedzieć, że współcześnie system ochrony zdrowia w Polsce został już zreformowany. Aby mógł on sprawnie działać, wymaga nie tylko kompleksowych reform, które dotyczą go bezpośrednio, ale musi być także powiązany z innymi wymiarami życia społecznego, gospodarką czy ekonomią, które to podlegają nieustannym przemianom.

\section{Bibliografia}

Archiwalia

Archiwum Akt Nowych

Posiedzenie Komisji Zdrowia z 10 sierpnia 1945 r., Referat Ministra Zdrowia, Biuro Prezydialne Krajowej Rady Narodowej Komitet Centralny, sygn. 76. Posiedzenie Komisji Zdrowia z 10 sierpnia 1945 r. Referat Ministra Zdrowia.

Rozporządzenie (projekt) Ministra Zdrowia w porozumieniu z Ministrami: Pracy i Opieki Społecznej, Oświaty, Administracji Publicznej i Ziem Odzyskanych „O strukturze organizacyjnej społecznej służby zdrowia, Ministerstwo Zdrowia, sygn. 22, k. 146. Zjazd Naczelników Wojewódzkich Wydziałów Zdrowia, Ministerstwo Zdrowia, sygn. 14.

\footnotetext{
${ }^{44}$ Dyrektywa Parlamentu Europejskiego i Rady 2011/24/UE z dnia 9 marca 2001 r. w sprawie stosowania praw pacjentów w transgranicznej opiece zdrowotnej, Dz. Urz. UE L 88 z 4.04.2011 r.

45 E. Nojszewska, System ochrony zdrowia..., s. 263 i n.
} 
Akty normatywne

Dyrektywa 2011/24/UE Parlamentu Europejskiego i Rady z dnia 9 marca 2011 roku w sprawie stosowania praw pacjentów w transgranicznej opiece zdrowotnej, Dz. Urz UE L $88 / 45$.

Konstytucja Rzeczypospolitej Polskiej z dnia 2 kwietnia 1997 roku, Dz.U. 1997 nr 78, poz. 483.

Ustawa z dnia 28 marca 1933 r. o obowiązkowym ubezpieczeniu społecznym, Dz.U. 1933 nr 51, poz. 396.

Ustawa z dnia 28 października 1948 r. o zakładach społecznych służby zdrowia i planowej gospodarce w służbie zdrowia, Dz.U. 1948 nr 55, poz. 434.

Ustawa z dnia 8 marca 1990 r. o samorządzie terytorialnym, Dz.U. 1990 nr 16, poz. 95.

Ustawa o z dnia 17 maja 1990 r. o podziale zadań i kompetencji określonych w ustawach szczególnych pomiędzy organy gminy a organy administracji rządowej oraz o zmianie niektórych ustaw, Dz.U. 1990 nr 34, poz. 198.

Ustawa z dnia 30 sierpnia 1991 r. o zakładach opieki zdrowotnej, Dz.U. 1991 nr 91, poz. 408.

Ustawa z dnia 24 listopada 1995 r. o zmianie zakresu działania niektórych miast oraz o miejskich strefach usług publicznych, Dz.U. 1995 nr 141, poz. 692.

Ustawa z dnia 6 lutego 1997 r. o powszechnym ubezpieczeniu zdrowotnym, Dz.U. 1997 nr 28, poz. 153

Ustawa z dnia 5 czerwca 1998 r. o samorządzie powiatowym, Dz.U. 1998 nr 91, poz. 578, Ustawa z dnia 5 czerwca 1998 r. o samorządzie województwa, Dz.U. 1998 nr 91, poz. 576.

Ustawa z dnia 23 stycznia 2003 r. o powszechnym ubezpieczeniu w Narodowym Funduszu Zdrowia, Dz.U. 2003 nr 45, poz. 391.

Ustawa z dnia 27 sierpnia 2004 r. o świadczeniach opieki zdrowotnej finansowanych ze środków publicznych, Dz.U. 2004 nr 210, poz. 2135

Ustawa z dnia 14 lipca 2006 r. o zmianie ustawy o zakładach opieki zdrowotnej oraz niektórych innych ustaw, Dz.U. 2006 nr 143, poz. 1032.

Ustawa z dnia 6 listopada 2008 r. o prawach pacjenta i Rzeczniku Praw Pacjenta, Dz.U. $2009 \mathrm{nr} 52$, poz. 417.

Ustawa z dnia 24 kwietnia 2009 r. przepisy wprowadzające ustawę o prawach pacjenta i Rzeczniku Praw Pacjenta, ustawę o akredytacji w ochronie zdrowia oraz ustawę o konsultantach w ochronie zdrowia, Dz.U. 2009 nr 76, poz. 641.

Ustawa z dnia 25 czerwca 2009 r. o zmianie ustawy o świadczeniach opieki zdrowotnej finansowanych ze środków publicznych oraz ustawy o cenach, Dz.U. $2009 \mathrm{nr}$ 118, poz. 989.

Ustawa z dnia 28 kwietnia 2011 r. o zmianie ustawy o prawach pacjenta i Rzeczniku Praw Pacjenta oraz ustawy o ubezpieczeniach obowiązkowych, Ubezpieczeniowym Funduszu Gwarancyjnym i Polskim Biurze Ubezpieczycieli Komunikacyjnych, Dz.U. 2011 nr 113, poz. 660. 
Wyrok Trybunału Konstytucyjnego z dnia 7 stycznia 2004 roku, sygn. akt K 14/03 stwierdzający niezgodność w całości ustawy z 2003 roku o powszechnym ubezpieczeniu w Narodowym Funduszu Zdrowia, Dz.U. 2003 nr 45, poz. 391.

\section{Źródta internetowe}

Janik J., Implementacja dyrektywy ws. transgranicznej opieki zdrowotnej: szanse i zagrożenia, http://www.rynekzdrowia.pl/Polityka-zdrowotna/Implementacja-dyrektywy-ws-transgranicznej-opieki-zdrowotnej-szanse-i-zagrozenia,128313,14.html (21.06.2014).

Ministerstwo Zdrowia, NPZ 2016-2020, https://www.gov.pl/web/zdrowie/npz-20162020 (dostęp: 25.02.2018)

Narodowy Program Zdrowia na lata 2007 - 2015, załącznik do uchwały nr 90/2007 Rady Ministrów z dnia 15 maja 2007, http://www2.mz.gov.pl/wwwfiles/ma_struktura/ docs/zal_urm_npz_90_15052007p.pdf(9.08.2018).

\section{Opracowania}

Aktualne zagadnienia stużby zdrowia [artykuł redakcyjny], „Dziennik Zdrowia” 1945, nr 1.

Dobska M., Rogoziński K., Podstawy zarządzania zakładem opieki zdrowotnej, Warszawa 2008.

Jastrzębowski Z., Spory o model lecznictwa. Opieka zdrowotna w koncepcjach polskiej polityki społecznej w XIX i XX wieku (do 1948 r.), Łódź 1994.

Karkowska D., Ustawa o prawach pacjenta i Rzeczniku Praw Pacjenta. Komentarz, Warszawa 2016.

Karski J.B., Polityka zdrowotna samorzadu terytorialnego, Warszawa 2009.

Koncepcje polityki społecznej w Polsce 1989-1991, red. J. Hrynkiewicz, raport BSE nr 12, Warszawa 1992.

Krotkiewska L., Rozwój administracji służby zdrowia w PRL, Warszawa 1968.

Leowski J., Polityka zdrowotna a zdrowie publiczne, Warszawa 2009.

Nojszewska E., System ochrony zdrowia w Polsce, Warszawa 2011.

Sadowska J., Unifikacja stużby zdrowia w Polsce w latach 1948-1951, „Zdrowie Publiczne" 2008, nr 1.

System ochrony zdrowia. Problemy i możliwości ich rozwiązań, red. E. Nojszewska, Warszawa 2011.

Więckowska E., Zwalczanie ostrych chorób zakaźnych w Polsce w latach 1944-1950, Wrocław 2001.

Włodarczyk W.C., Polityka zdrowotna $w$ społeczeństwie demokratycznym, Łódź-Kraków 1996.

Włodarczyk W.C., Reforma opieki zdrowotnej w Polsce. Studium polityki zdrowotnej, Kraków 1998. 
Włodarczyk W.C., Reformy zdrowotne, Kraków 2003.

Woch M., Instytucje kształtujace system opieki zdrowotnej w Polsce (Analiza prawno-porównawcza lat 1918-2004), Warszawa 2012.

Zdrowie publiczne, red. A. Czupryna, S. Poździoch, A. Ryś, W.C. Włodarczyk, Kraków 2001. Zdrowie publiczne, red. T.B. Kulik, M. Latalski, Lublin 2002.

Zdrowie $w$ medycynie $i$ naukach społecznych, red. T.B. Kulik, I. Wrońska, Stalowa Wola 2000.

\begin{abstract}
Abstrakt
Celem artykułu jest ukazanie modelu ochrony zdrowia, sposobu jego kształtowania w okresie Polski Ludowej oraz w III Rzeczypospolitej Polskiej. W latach 1945-2009 w Polsce system ochrony zdrowia uległ różnorodnym przeobrażeniom. Jego charakter był uzależniony od aktualnie panujących warunków społecznych, gospodarczych, politycznych. W Polsce poszukiwanie modelu ochrony zdrowia przebiegało od powszechnej służby zdrowia obejmującej lata 1948-1991 do publicznej ochrony zdrowia, której podstawę do funkcjonowania dała ustawa o zakładach opieki zdrowotnej z 1991 roku.
\end{abstract}

\title{
In Search for a Model of Health in Poland after WW2 - from the State's Health Service to the Public Health Care (1945-2009)
}

\begin{abstract}
The aim of this article is to present a model of health care, its configuration during People's Poland and the III Republic of Poland. In the years 1945-2009 Polish health care system underwent profound changes and was affected by country's social, economic and political situation. In Poland the model of health care proceeded from universal health care in the years of 1948-1991 to public health care which was based on the act on health care public services of 1991.
\end{abstract}

